\title{
Percutaneous interventions in patients with hypoplastic left heart syndrome after stage first Norwood operation
}

Zabiegi kardiologii interwencyjnej u pacjentów z zespołem hipoplazji lewego serca po pierwszym etapie leczenia metodą Norwooda

\author{
Tomasz Moszura ${ }^{1,2}$, Paweł Dryżek ${ }^{1}$, Waldemar Bobkowski², Sebastian Góreczny' ${ }^{1}$, Anna Mazurek-Kula', \\ Jadwiga A. Moll', Jacek J. Moll ${ }^{3}$, Andrzej Sysa ${ }^{1}$
}

1Department of Cardiology, Polish Mother's Memorial Hospital, Research Institute, Lodz, Poland

2Department of Paediatric Cardiology and Nephrology, Poznan Medical University of Sciences, Poland

3Department of Cardiosurgery, Polish Mother's Memorial Hospital, Research Institute, Lodz, Poland

Post Kardiol Interw 2011; 7, 4 (26): 277-284

DOI: $10.5114 /$ pwki.2011.25785

\begin{abstract}
Background: Hypoplastic left heart syndrome (HLHS) still remains a therapeutic challenge due to complex anatomical and haemodynamic abnormalities. The multistage treatment leads to consequences and complications limiting the efficacy of surgery and necessitating additional percutaneous interventions.

Aim: To evaluate the type of necessary percutaneous interventions in patients after stage first Norwood operation for HLHS with a focus on different techniques and equipment and to determine the efficacy of interventional treatment.

Material and methods: Between 2001 and 2010 we conducted 161 interventions in 88 patients with HLHS at all stages of palliation. We performed 47 interventions in 38 patients after stage first Norwood operation. The main reasons for percutaneous treatment in this group were as follows: stenosis of the aortic arch/isthmus (20 patients), stenosis of the Sano shunt (8), proximal pulmonary arteries stenosis (6) and secondary restriction of the atrial communication (4).

Results: In the group of 20 infants with stenosis of the aortic arch/isthmus balloon angioplasty allowed widening of the stenosis from $2.87 \pm 0.82 \mathrm{~mm}$ to $5.15 \pm 0.82 \mathrm{~mm}(p<0.05)$ and a decrease of the systolic pressure gradient between the aortic arch and the descending aorta from $29.38 \pm 15.40 \mathrm{mmHg}$ to $7.14 \pm 4.28 \mathrm{mmHg}(p<0.05)$. In 1 patient a stent was implanted due to rapid recurrence of the stenosis. In the group of 8 patients with critical stenosis of the right ventricle to pulmonary artery shunt successful interventions were done in 7 infants (87\%). In 5 cases (62\%) percutaneous balloon angioplasty turned out to be a sufficient treatment. Two patients (25\%) required implantation of a stent to the Sano shunt. Oxygen saturation increased from $52 \pm 12 \%$ to $75 \pm 4 \%(p=0.002)$ and the diameter of the stenosis increased from $2.28 \pm 0.48 \mathrm{~mm}$ to $4.14 \pm 0.69 \mathrm{~mm}(p=0.0025)$. Six patients after stage first of the surgical palliation required balloon angioplasty of the tight proximal pulmonary artery stenosis. The diameter of the stenosis increased from $2.33 \pm 0.51 \mathrm{~mm}$ to $3.58 \pm 0.49 \mathrm{~mm}(p=0.0099)$; however, the decrease of the pressure gradient from $3.33 \pm 1.63 \mathrm{mmHg}$ to $2.5 \pm 1.05 \mathrm{mmHg}$ was statistically insignificant. Secondary restriction of the atrial communication was successfully treated in all 4 patients. The diameter of the connection increased from $4.2 \pm 1.15 \mathrm{~mm}$ to $9.9 \pm 3.17 \mathrm{~mm}(p=0.0079)$ and left atrial pressure decreased from $19.4 \pm 4.1 \mathrm{mmHg}$ to $13.8 \pm 2.4 \mathrm{mmHg}(p=0.0075)$. In half of the patients it was sufficient to perform static atrioseptostomy whereas the second half required stent implantation.

Conclusions: Percutaneous interventions lead to haemodynamic stabilization prior to the next step of treatment, increase arterial oxygen saturation and decrease pulmonary arterial pressure, therefore lowering the number of required operations. Rescue interventions such as stenting of the interatrial septum or critically stenosed Sano shunt should be considered in deteriorating patients even despite the risk of complications.
\end{abstract}

Key words: hypoplastic left heart syndrome, interventional treatment

\section{Streszczenie}

Wstęp: Zespół niedorozwoju lewego serca (hypoplastic left heart syndrome - HLHS) ze względu na złożony charakter nieprawidłowości anatomicznych i hemodynamicznych stanowi nadal trudny problem terapeutyczny. W procesie wieloetapowego leczenia

Corresponding author/Adres do korespondencji:

Sebastian Góreczny MD, Department of Cardiology, Polish Mother's Memorial Research Institute, 281/289 Rzgowska, $93-338$ Lodz, Poland, tel.: +48 4227121 84, fax: +48 42271 14 78, e-mail: sebstiangoreczny@yahoo.pl

Praca wptynęta: 12.09.2011, przyjęta do druku: 28.10.2011. 
wciąż występują określone następstwa i powikłania, które zmniejszają skuteczność leczenia operacyjnego i zmuszają do wykonywania dodatkowych zabiegów interwencyjnych.

Cel: Ocena charakteru niezbędnych zabiegów interwencyjnych u pacjentów z HLHS po pierwszym etapie leczenia metodą Norwooda, z uwzględnieniem różnych technik i rodzaju sprzętu oraz określenie skuteczności kardiologicznego leczenia interwencyjnego.

Materiał i metody: W latach 1999-2010 w Pracowni Hemodynamiki Kliniki Kardiologii Instytutu Centrum Zdrowia Matki Polki w Łodzi wykonano 161 procedur kardiologii interwencyjnej u 88 dzieci z HLHS na poszczególnych etapach leczenia. U 38 pacjentów po pierwszym etapie wykonanym metodą Norwooda przeprowadzono 47 interwencji przezskórnych. Głównym problemem w tej grupie było zwężenie łuku lub cieśni aorty (20 pacjentów), zwężenie zespolenia komorowo-płucnego (8), zwężenie proksymalne gałęzi płucnych (6) oraz wtórna restrykcja na połączeniu międzyprzedsionkowym (4).

Wyniki: W grupie 20 dzieci ze zwężeniem łuku lub cieśni aorty przezskórne zabiegi angioplastyki balonowej pozwoliły na poszerzenie zwężenia z wyjściowo 2,87 $\pm 0,82 \mathrm{~mm}$ do 5,15 $\pm 0,82 \mathrm{~mm}(p<0,00001)$, z obniżeniem gradientu ciśnienia skurczowego z $29,38 \pm 15,40 \mathrm{mmHg}$ do $7,14 \pm 4,28 \mathrm{mmHg}(p=0,00006)$ oraz ciśnienia skurczowego powyżej zwężenia z 86,52 $\pm 16,44 \mathrm{mmHg}$ do $81,38 \pm 15,65 \mathrm{mmHg}(p=0,0367)$. U 7 (87\%) z grupy 8 dzieci z ciasnym zwężeniem zespolenia komorowo-płucnego wykonano skuteczne zabiegi interwencyjne. W 5 przypadkach (62\%) wystarczało przeprowadzenie przezskórnej angioplastyki balonowej, w 2 przypadkach (25\%) implantowano stenty wewnątrznaczyniowe do zespolenia Sano. Uzyskano wzrost saturacji tlenem krwi tętniczej po zabiegu z $52 \pm 12 \%$ do $75 \pm 4 \%(p=0,002)$ oraz wzrost średnicy zwężenia z 2,28 $\pm 0,48 \mathrm{~mm}$ do $4,14 \pm 0,69 \mathrm{~mm}(p=0,0025)$. U $6 \mathrm{dzieci}$ wykonano angioplastykę proksymalnego zwężenia gałęzi płucnych. Uzyskano poszerzenie zwężenia z 2,33 $\pm 0,51 \mathrm{~mm}$ do $3,58 \pm 0,49 \mathrm{~mm}$ $(p=0,0099)$ oraz nieistotne statystycznie $(p=0,1851)$ zmniejszenie bezpośredniego gradientu ciśnienia skurczowego przez zwężenie z 3,33 $\pm 1,63 \mathrm{mmHg}$ do $2,5 \pm 1,05 \mathrm{mmHg}$. Wtórna restrykcja połączenia międzyprzedsionkowego była wskazaniem do interwencji u 4 dzieci. U wszystkich pacjentów uzyskano skuteczne powiększenie połączenia międzyprzedsionkowego z 4,2 $\pm 1,15 \mathrm{~mm}$ do 9,9 $\pm 3,17 \mathrm{~mm}(p=0,0079)$, z obniżeniem ciśnienia w lewym przedsionku z 19,4 $\pm 4,1 \mathrm{mmHg}$ do 13,8 $\pm 2,4 \mathrm{mmHg}(p=0,0075)$. W połowie przypadków wystarczające były zabiegi przezskórnej atrioseptostomii statycznej, u pozostałej dwójki dzieci implantowano stent do przegrody międzyprzedsionkowej.

Wnioski: Przezskórne interwencje u pacjentów z HLHS po operacji sposobem Norwooda pozwalają na stabilizację stanu hemodynamicznego przed kolejnymi etapami leczenia, a w rezultacie redukcję liczby zabiegów chirurgicznych. Prezentowane nietypowe, ratunkowe zabiegi kardiologii interwencyjnej, takie jak stentowanie przegrody międzyprzedsionkowej czy krytycznie zwężonego zespolenia Sano, pomimo ryzyka powikłań, powinny być brane pod uwagę, gdy stan dziecka jest ciężki, a potencjalne korzyści z zabiegu są wymierne.

Słowa kluczowe: zespół hipoplazji lewego serca, leczenie interwencyjne

\section{Introduction}

Hypoplastic left heart syndrome (HLHS) remains a therapeutic challenge due to the complex character of anatomical and haemodynamic abnormalities. The progress in surgical treatment of congenital heart diseases which took place in the last decade significantly improved prognosis of children with HLHS. Nevertheless, multistage treatment still leads to certain consequences and complications limiting the efficacy of surgical procedures and requiring additional percutaneous interventions. The main problems include stenosis of the aortic arch/ isthmus, stenosis of the right ventricle to pulmonary artery shunt or pulmonary arteries as well as primary and secondary restriction of the interatrial communication. Currently used, modern methods of interventional treatment support and partially replace the surgical procedures. These procedures may be successfully used before, during and after each stage of treatment in patients with HLHS.

\section{Aim}

The aim of the study was to evaluate the type of the required percutaneous interventions in patients after Norwood operation for HLHS before the $2^{\text {nd }}$ stage of treatment with a focus on different techniques and equipment and to determine the efficacy of interventional treatment.

\section{Material and methods \\ Patients}

There were 161 percutaneous interventions in 88 patients with HLHS at all stages of palliation performed between 2001 and 2010 in the Catheterization Laboratory of the Department of Cardiology, Polish Mother's Memorial Research Institute. There were 47 interventions in 38 patients after stage first Norwood operation. The main reasons for percutaneous treatment in this group were stenosis of the aortic arch/isthmus (20 patients), stenosis of the right ventricle to pulmonary artery shunt (8), stenosis of the proximal pulmonary arteries (6), and secondary restriction of the interatrial communication (4) (Figure 1).

\section{Procedures}

Interventional treatment of the aortic arch/isthmus stenosis was attempted in 20 infants between 2 months and 9 months of age. Maximal gradient across the stenosis ranged between $14 \mathrm{mmHg}$ and $82 \mathrm{mmHg}$ with minimal stenosis diameter between $1.5 \mathrm{~mm}$ and $4.5 \mathrm{~mm}$. Venous access was used in 15 infants and arterial access in 5 of them.

The latter was used in case of difficulties with balloon placement and in case of disadvantageous anatomical localization of the primary aorta and a risk of coronary 
inflow cessation by a balloon catheter (Figure 2). Arterial access was also used during stent implantation and in one case where an attempt to cross with the balloon catheter through the venous system led to a transient $3^{\text {rd }}$ degree AV block.

Both low pressure TYSHAK balloon catheters (NuMed) and high pressure Advance (Cook) and OPTA (Corids) catheters were used. Catheter diameter was adjusted to the diameter of the descending aorta below the stenosis (balloon diameter ranging from +0 to $+2 \mathrm{~mm}$ ). Procedures were performed without general heparinization, but lowmolecular weight heparin was used directly after the procedure (Fragmin $100 \mathrm{IU} / \mathrm{kg}$ for 3 days). All patients were on chronic treatment with acetylsalicylic acid (Acesan $3 \mathrm{mg} / \mathrm{kg}$ ) which was not interrupted for the procedure due to central cyanosis and blood inflow through a Sano shunt.

Lifesaving procedures were performed in 8 infants with stenosis of the right ventricle to pulmonary artery shunt. The age of infants ranged from 1.5 months to 5 months, while arterial blood oxygenation during mechanical ventilation with $100 \%$ oxygen was between $28 \%$ and $67 \%$. Minimal diameter of the Sano shunt stenosis ranged between $1.5 \mathrm{~mm}$ and $3 \mathrm{~mm}$ with predominantly proximal, periventricular localization (7/8). Interventional treatment consisted of low and high pressure balloon angioplasty and stent implantation at the site of stenosis.

There were 6 children with proximal stenosis of the left (4) and right (2) pulmonary artery. Low pressure balloon angioplasty with the use of a THYSAK balloon catheter was performed in 4 cases and high pressure balloon angioplasty with means of a coronary balloon catheter (Aqua) was done in 2 cases. Procedures were performed through the venous access after placement of the coronary guidewire in the lobular arteries of the dilated branch. The balloon catheter was introduced directly through the Sano shunt without the use of a long introducing sheath. Diameter of the balloon ranged from $4 \mathrm{~mm}$ to $6 \mathrm{~mm}$. Due to the need of intervention through the Sano shunt heparin was administered during the procedure. Standard management after stent implantation was used.

Four infants between 6 months and 12 months of age required interventional treatment due to secondary restriction of the interatrial communication. Left-to-right gradient through the interatrial communication ranged from $8 \mathrm{mmHg}$ to $15 \mathrm{mmHg}$ with mean left atrial pressure of $15 \mathrm{mmHg}$ to $24 \mathrm{mmHg}$. Restrictive flow was registered despite free interatrial communication during stage first of the Norwood operation. Transfemoral access was used for the procedures. The procedure had to be repeated in one infant. At this stage of treatment patients were not qualified for further bidirectional Glenn treatment due to secondary increase of pulmonary pressure. Static balloon atrioseptostomy was done in 2 infants aged 4 months and 7 months (communication diameter $4 \mathrm{~mm}$ and $3.5 \mathrm{~mm}$ ). The result of the procedure was controlled with trans-

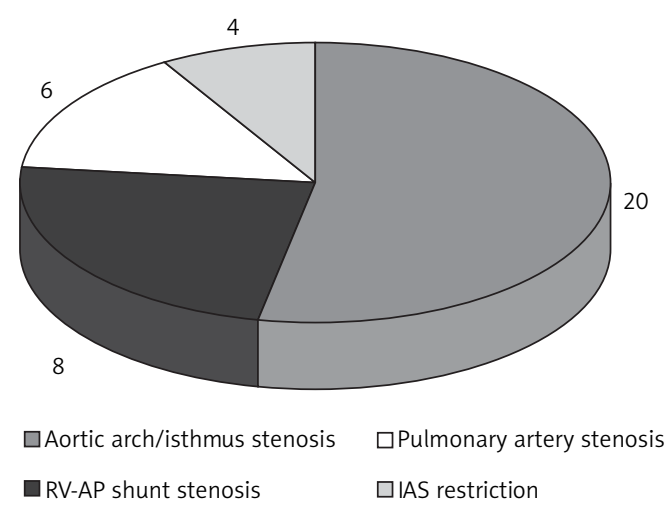

Fig. 1. Patients with HLHS after stage first Norwood operation who underwent interventional treatment. Data distribution according to the indication for intervention

Ryc. 1. Pacjenci z HLHS po pierwszym etapie leczenia sposobem Norwooda poddani zabiegom interwencyjnym. Podział ze względu na wskazanie do interwencji

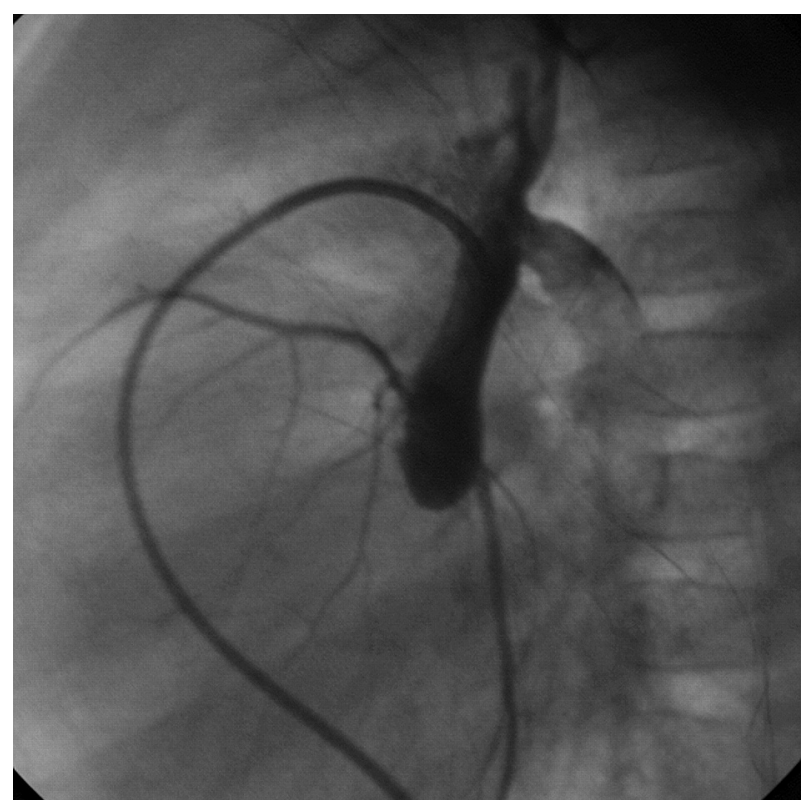

Fig. 2. Angiographic view of the ascending aorta and coronary arteries. Stenosis located at the site of connection with descending aorta

Ryc. 2. Obraz angiograficzny wstecznie zakontrastowanej aorty wstępującej z odejściem naczyń wieńcowych. Widoczne zwężenie w miejscu połaczenia z aortą zstępująca

thoracic echocardiography. Continuous measurement of the blood pressure during retraction of the diagnostic catheter from the left pulmonary veins to the inferior vena cava was performed.

In 2 infants interatrial communication was dilated by stent implantation. Qualification in that case was based 
Table 1. Results of percutaneous treatment in patients with HLHS after stage first Norwood operation

Tabela 1. Wyniki leczenia interwencyjnego pacjentów z HLHS po pierwszym etapie terapii sposobem Norwooda

\begin{tabular}{|c|c|c|c|}
\hline Parameter & Before the intervention & After the intervention & Value of $p$ \\
\hline CoA diameter $[\mathrm{mm}]$ & $2.87 \pm 0.82$ & $5.15 \pm 0.82$ & $<0.05$ \\
\hline Systolic pressure above CoA [mmHg] & $86.52 \pm 16.44$ & $81.38 \pm 15.65$ & $<0.05$ \\
\hline Gradient across CoA [mmHg] & $29.38 \pm 15.40$ & $7.14 \pm 4.28$ & $<0.05$ \\
\hline Diameter of the RV-AP shunt stenosis [mm] & $2.28 \pm 0.48$ & $4.14 \pm 0.69$ & $<0.05$ \\
\hline Arterial blood oxygenation [\%] & $52 \pm 12$ & $75 \pm 4$ & $<0.05$ \\
\hline Pulmonary artery stenosis diameter [mmHg] & $2.33 \pm 0.51$ & $3.58 \pm 0.49$ & $<0.05$ \\
\hline Gradient across pulmonary artery stenosis [ $\mathrm{mmHg}]$ & $3.33 \pm 1.63$ & $2.5 \pm 1.05$ & NS \\
\hline Diameter of the IAS defect [mm] & $4.2 \pm 1.15$ & $9.9 \pm 3.17$ & $<0.05$ \\
\hline LA pressure [mmHg] & $19.4 \pm 4.1$ & $13.8 \pm 2.4$ & $<0.05$ \\
\hline
\end{tabular}

mainly on the echocardiographic picture of the stiff septum with more then $2 \mathrm{~mm}$ thickness. A Palmaz-Genesis stent was implanted into the interatrial septum in both cases. The procedure was preceded by administration of $100 \mathrm{IU} / \mathrm{kg}$ of unfractionated heparin and followed by administration of $100 \mathrm{lU} / \mathrm{kg}$ of low molecular weight heparin (Fragmin) for 3 days. Acetylsalicylic acid (Acesan at $3 \mathrm{mg} / \mathrm{kg}$ ) was given for the whole period beginning with stent implantation. Monitoring of stent position with transoesophageal echocardiography was used.

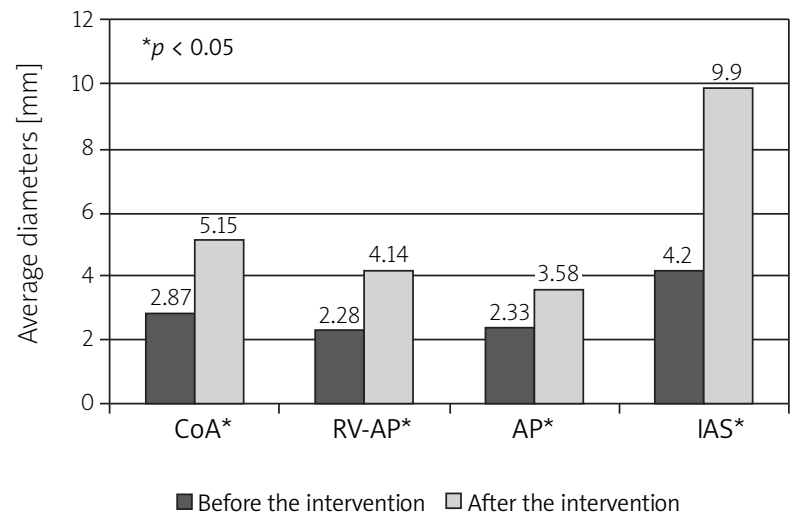

Fig. 3. Average diameters of stenosis of the aortic arch/isthmus, RV-AP graft, pulmonary artery and interatrial septum before and after the intervention See Table 1 for abbreviations

Ryc. 3. Średni wymiar zwężenia kolejno tuku lub cieśni aorty, graftu RV-AP, zwężenia tętnicy płucnej, potączenia międzyprzedsionkowego (IAS) przed interwencja i po interwencji

Skróty jak $w$ tabeli 1.

\section{Statistical analysis}

Arithmetic mean, median and standard deviation as a measure of data distribution were used to describe systolic, diastolic and mean blood pressure, stenosis diameter, pressure gradients and increase of arterial blood oxygenation at various stages of treatment. Shapiro-Wilk test was used to test for normality of distribution of the above parameters. Student's $t$-test for independent samples was applied to compare pre- and postprocedural parameters with normal distribution. Variables without normal distribution were compared using a non-parametric Wilcoxon test. All statistical analysis were performed by means of the statistical software STATISTICA, StatSoft, Inc. (2007) v 8.0.

\section{Results}

In the group of 20 infants with recoarctation low and high pressure balloon angioplasty procedures led to widening of the stenosis from $2.87 \pm 0.82 \mathrm{~mm}$ to 5.15 $\pm 0.82 \mathrm{~mm}(p<0.05)$ and to a decrease of systolic pressure gradient between the aortic arch and descending aorta from $29.38 \pm 15.40 \mathrm{mmHg}$ to $7.14 \pm 4.28 \mathrm{mmHg}(p<0.05$, Table 1). Decrease of systolic pressure above the stenosis was also obtained $(86.52 \pm 16.44 \mathrm{mmHg}$ to 81.38 $\pm 15.65 \mathrm{mmHg}, p=0.0367)$. Rapid recurrence of the stenosis in 1 patient required implantation of the $7 \mathrm{~mm} \times$ $18 \mathrm{~mm}$ Palmaz-Genesis stent (Figures 3 and $4 \mathrm{~A}-\mathrm{C}$ ). The direct postprocedural pressure gradient across the stenosis was lower than or equal to $5 \mathrm{mmHg}$ in 9 infants (45\%), ranged between $5 \mathrm{mmHg}$ and $10 \mathrm{mmHg}$ in the next 4 of them (20\%), and was higher than or equal to $10 \mathrm{mmHg}$ in 7 infants (35\%), which was an indication for repeated balloon angioplasty during catheterization performed after stage 2 of treatment (Figure 5). 

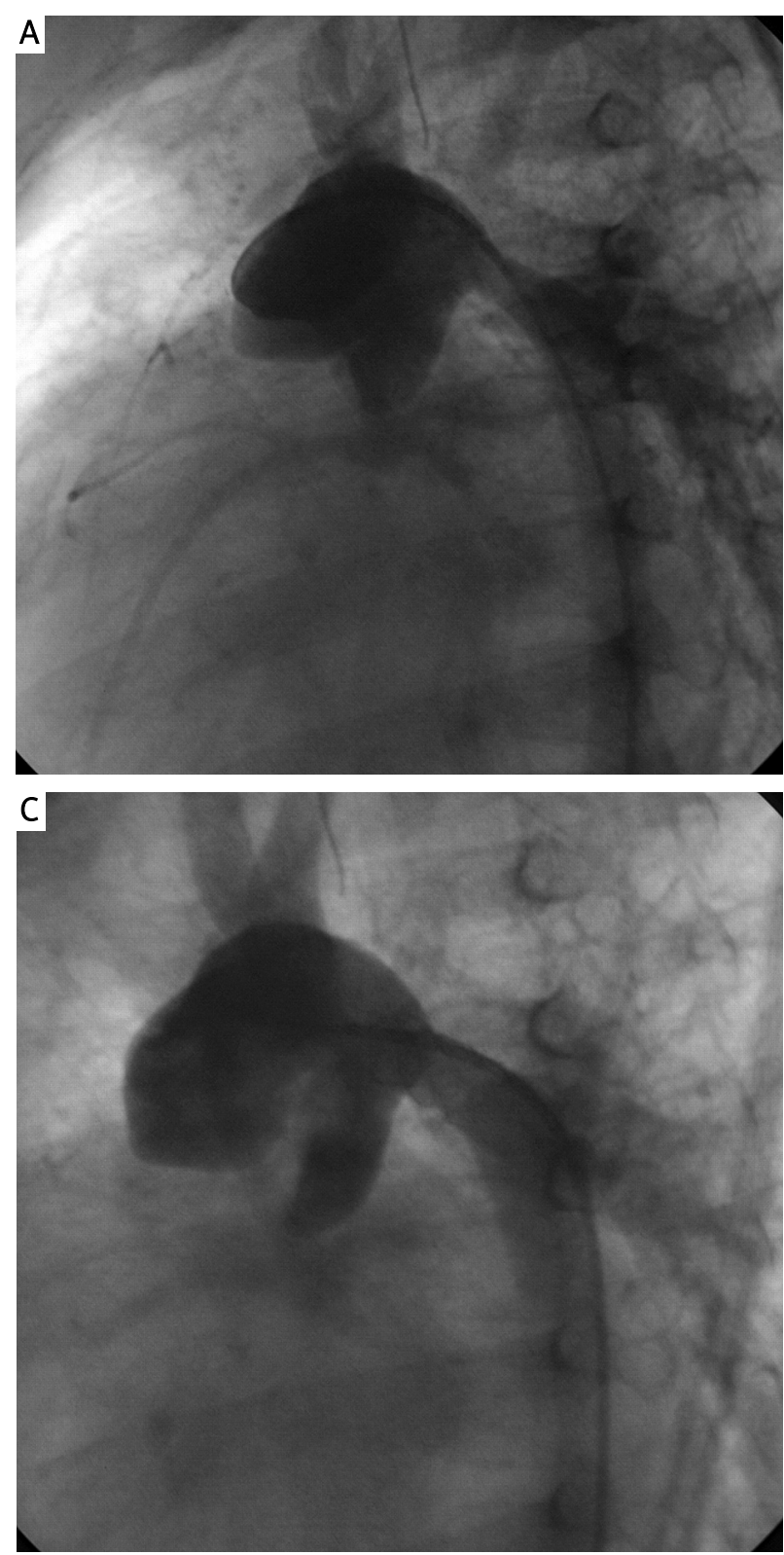

Critical stenosis of the right ventricle to pulmonary artery shunt was treated successfully in 7 of the 8 infants (87\%). Percutaneous balloon angioplasty was sufficient in 5 cases $(62 \%)$, while in 2 cases (25\%) intra-arterial stents were implanted into the Sano shunt. Arterial blood oxygen increased from $52 \pm 12 \%$ to $75 \pm 4 \%(p=0.002)$ and the diameter of the stenosis increased from $2.28 \pm 0.48 \mathrm{~mm}$ to $4.14 \pm 0.69 \mathrm{~mm}(p=0.0025)$.

In 1 case the stent was pulled back from the Sano shunt into the right ventricle during retraction of the balloon catheter. After stabilization of the stent within the right ventricle with the use of a guidewire the child was referred for bidirectional Glenn surgery with removal of the stent from the right ventricle.

Six patients after stage first of the surgical palliation underwent balloon angioplasty of the tight proximal

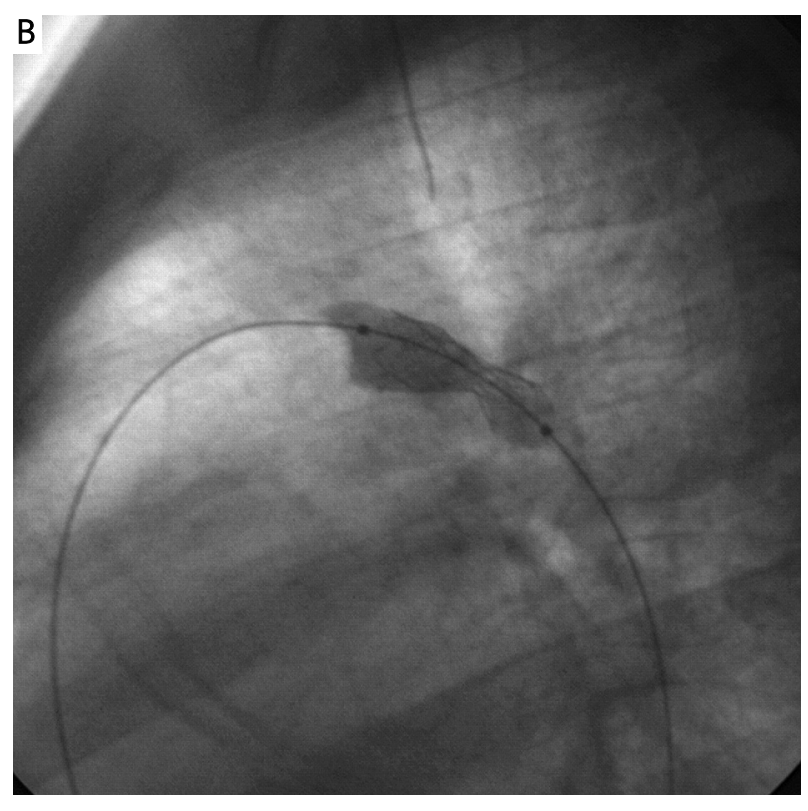

Fig. 4. Balloon angioplasty with Palmaz-Genesis stent implantation for stenosed aortic arch/isthmus in patient with HLHS after Norwood operation. Angiographic view of aortic arch and descending aorta before (A), during stent implantation (B) and after the intervention (C)

Ryc. 4. Angioplastyka balonowa zwężenia tuku lub cieśni aorty z implantacją stentu Palmaz-Genesis u pacjenta po leczeniu metoda Norwooda. Obraz angiograficzny tuku aorty i aorty zstępującej przed zabiegiem (A), w trakcie rozprężania stentu (B) oraz po zabiegu (C)

pulmonary artery stenosis with the balloon catheter introduced through the Sano shunt. The diameter of stenosis increased from $2.33 \pm 0.51 \mathrm{~mm}$ to $3.58 \pm 0.49 \mathrm{~mm}$ ( $p=0.0099$ ); however, decrease of the pressure gradient from $3.33 \pm 1.63 \mathrm{mmHg}$ to $2.5 \pm 1.05 \mathrm{mmHg}$ was statistically insignificant.

In patients with secondary restriction of the interatrial communication was successfully widened from $4.2 \pm 1.15 \mathrm{~mm}$ to $9.9 \pm 3.17 \mathrm{~mm}(p=0.0079)$ and left atrial pressure decreased from $19.4 \pm 4.1 \mathrm{mmHg}$ to 13.8 $\pm 2.4 \mathrm{mmHg}(p=0.0075)$. In half of the patients it was sufficient to perform static atrioseptostomy whereas the second half required stent implantation into the IAS (Figure 7). In 1 case the implanted stent was successfully redilated due to hypertrophy and recurrence of restriction. 


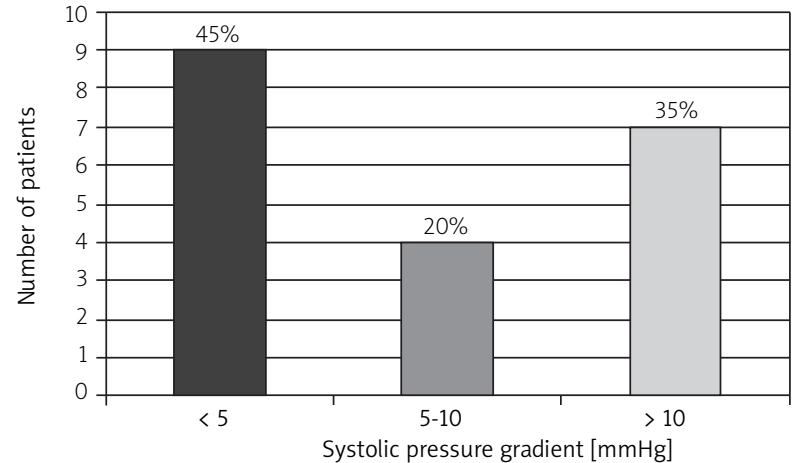

Fig. 5. Systolic pressure gradient after interventional dilatation of stenosed aortic arch/isthmus Ryc. 5. Gradient ciśnienia skurczowego po interwencyjnym poszerzeniu łuku lub cieśni aorty

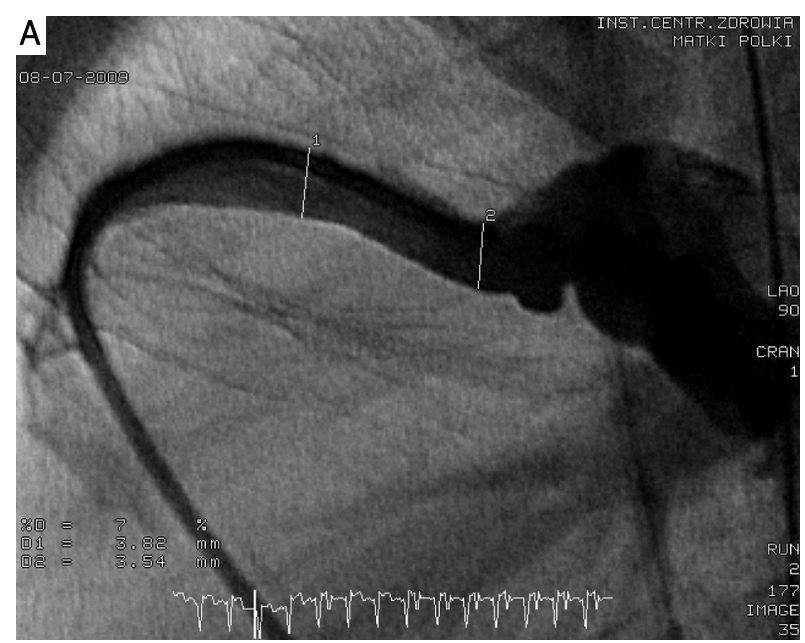

C

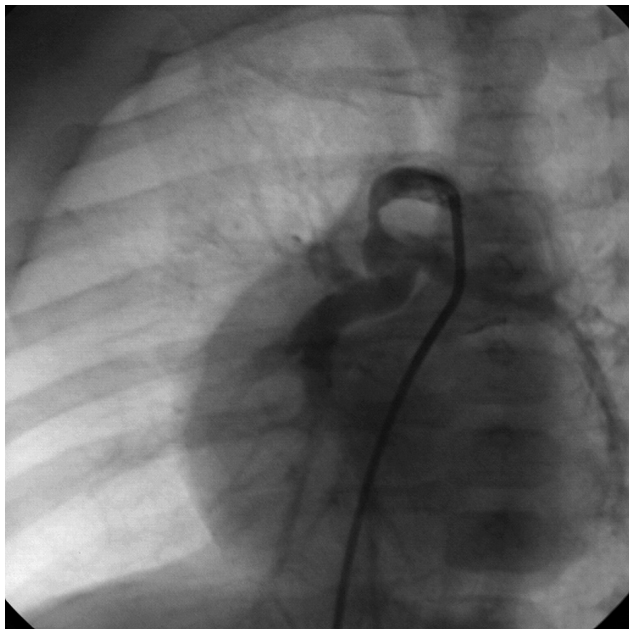

\section{Discussion}

Therapeutic management of children with HLHS is multistage and carries a significant risk of complications. A special group of problematic patients includes those with suboptimal results of the multistage treatment requiring additional interventional procedures due to various complications [1-4].

The estimated frequency of recoarctation in patients after the Norwood procedure ranges from $9.2 \%$ to $20 \%$ [5]. In spite of the functionally right ventricular character of the single ventricle heart, it seems reasonable to consider early qualification for intervention when the direct gradient across the aortic arch/isthmus stenosis exceeds $10 \mathrm{mmHg}[1,3,6]$.

This situation is justified by different physiology of the systemic right ventricle in which increased pressure overload potentially leads to the onset or progression of

B

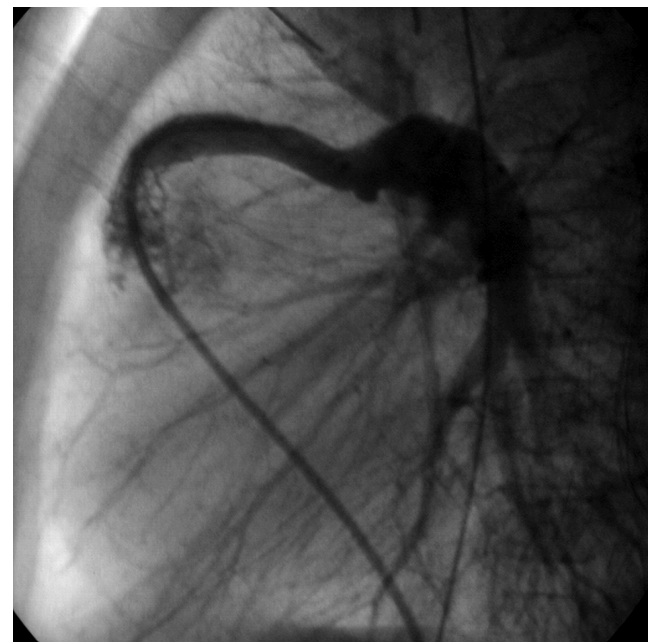

D

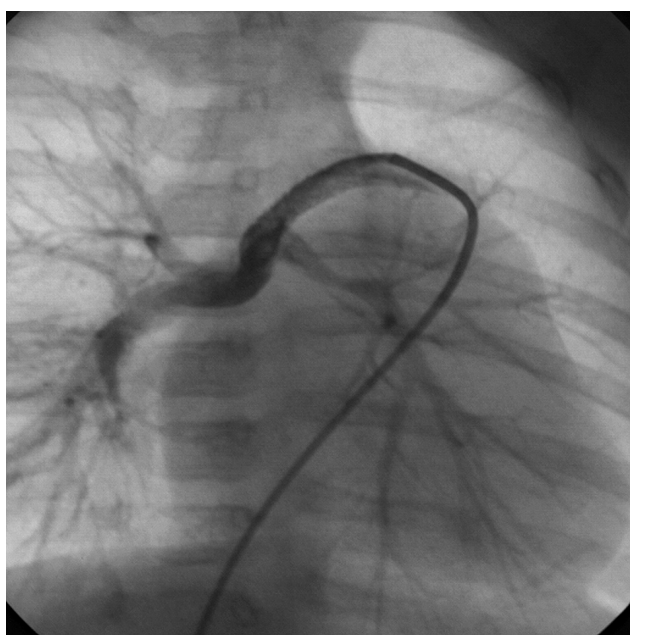

Fig. 6. Angiographic view of the proximal critical stenosis of the RV-AP shunt (A). Palmaz-Genesis stent implanted into the proximal segment of RV-AP shunt (B). Angiographic view of the patient with distal stenosis of the RV-AP shunt before (C) and after Coroflex stent implantation (D)

Ryc. 6. Obraz angiograficzny ciasnego, proksymalnego zwężenia zespolenia komorowo-płucnego (A). Stent Palmaz-Genesis implantowany w zwężenie proksymalne zespolenia komorowo-płucnego (B). Obraz angiograficzny pacjenta ze zwężeniem dystalnym zespolenia komorowo-płucnego (C) z widocznym stentem Coroflex (D) 
the tricuspid valve regurgitation. The end-point for intervention was defined as reduction of the direct gradient by at least $70 \%$ in comparison to the baseline values or as gradient reduction $\leq 10 \mathrm{mmHg}$. In most cases of recoarctation, balloon angioplasty was performed with venous access, which certainly decreased the risk of significant, local vascular complications, more frequently present after femoral artery puncture. On the other hand, there was a higher risk of arrhythmia and conduction abnormalities related to introduction of a stiff balloon catheter through the systemic right ventricle.

The success of surgical treatment of patients with HLHS depends mainly (as in most children with a so-called single ventricle heart) on the restoration of optimal morphological and haemodynamic parameters of the pulmonary circulation. The presence of stenoses or segmental hypoplasia of the pulmonary branches increases the risk of additional procedures [7]. The Norwood operation results in the change of geometry of the pulmonary vessels and the frequency of proximal stenosis, especially in patients treated using a Sano modification, is estimated to range between $42 \%$ and $58 \%$ [8].

Despite higher frequency of proximal stenoses, the Sano modification leads to reduction of mortality after stage first of treatment and better stimulates the development of peripheral pulmonary vessels in comparison to the Blalock-Taussig shunt. If the only pulmonary circulation inflow tract consist of the Sano shunt, isolated balloon angioplasty should be used despite the known lack of permanent effect of treatment. Stent implantation may be attempted intraoperatively simultaneously to treatment with bidirectional Glenn or directly after the surgery [9].

Restrictive interatrial communication in patients with HLHS is a significant determinant of the negative result of surgical treatment [10-12]. The presence of free interatrial flow after the Norwood stage first operation indirectly affects the normal pulmonary pressure values and is one of the elements determining success of the bidirectional Glenn procedure. This problem may have the form of a primary restriction of the interatrial communication leading to increased pulmonary pressure already in the fetal period and causing changes of the small pulmonary arteries which limit the chances for any type of palliative procedure after birth. In a small subset of children a secondary restriction of the communication occurs despite excision of the interatrial septum which is caused by the gradual growth of the interatrial septum. Percutaneous intervention may be an alternative to surgery in both of these situations [11, 12].

In the presented cases, decompression of the left atrium consisted of balloon angioplasty (static atrio septostomy) or intravascular stent implantation into the interatrial septum. The first method is more effective in the case of a thinner interatrial septum but the final result of the procedure, especially the width of the communication, may

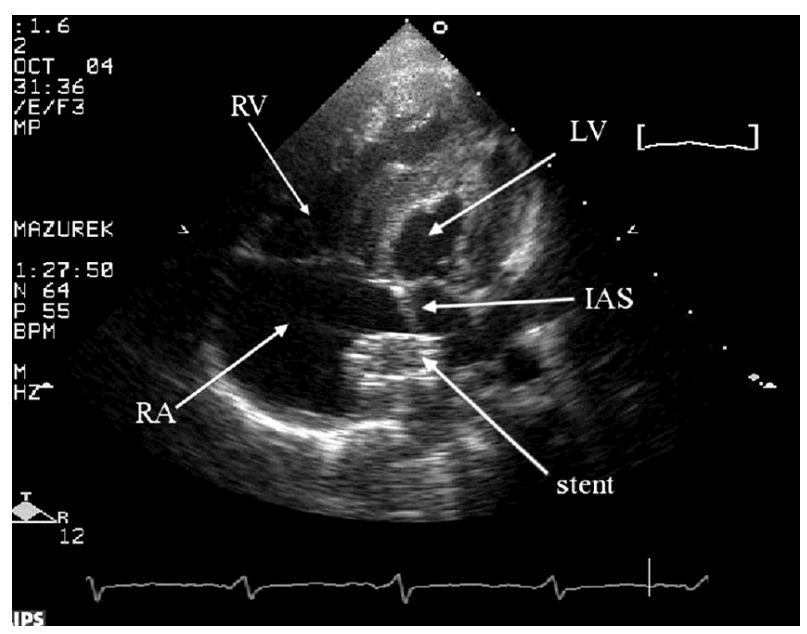

Fig. 7. Transthoracic echocardiography - four-chamber view. Image of the stent implanted into the interatrial septum

$R A$ - right atrium, $R V$ - right ventricle, $L V$ - left ventricle, IAS - interatrial septum

Ryc. 7. Badanie echokardiograficzne przezklatkowe - projekcja czterojamowa. Obraz stentu implantowanego do przegrody międzyprzedsionkowej $R A$ - prawy przedsionek, $R V$ - prawa komora, $L V$ - lewa komora, IAS - przegroda międzyprzedsionkowa

not be objectively measured [13]. Stent implantation into the interatrial septum is reserved for cases of stiff and thickened interatrial septum and requires the introduction of antithrombotic treatment, which is not necessary after balloon atrioseptostomy $[4,11,12]$. Stents are removed during the next stages of surgical treatment with the use of extracorporeal circulation. Because of the large number of complications, especially deaths in patients undergoing atrioseptostomy using a Park blade, this technique was not used in infants [13].

The Sano modification consisting of the right ventricle to pulmonary artery shunt implantation reduces mortality after stage first of treatment. The occurrence of tight shunt stenosis is a direct threat to life and requires emergency treatment. The clinical condition of an infant is usually very severe, with significant hypoxia and acidosis and therefore interventional procedures allowing widening of the stenosis are useful. Published data demonstrate that interventional treatment is based on stent implantation into the stenosis (most frequently coronary stents). In the presented material the authors performed initial predilation of the stenosis with a balloon catheter while a decision to implant a stent was based on the effect of angioplasty - increase of arterial blood oxygenation and widening of stenosis. Initially stents were implanted without the use of a long introducing sheath [14, 15] and subsequently after placement of the sheath tip inside the right ventricle. 


\section{Conclusions}

Percutaneous interventions in patients with HLHS after stage first of the Norwood operation lead to haemodynamic stabilization prior to the next step of treatment, increase of oxygen arterial blood saturation and decrease pulmonary arterial pressure, therefore lowering the number of required operations.

Atypical, rescue interventions such as stenting of the interatrial septum or critically stenosed Sano shunt should be considered in deteriorating patients despite the risk of complications if there are measurable potential benefits.

\section{References}

1. Moszura T, Mazurek-Kula A, Dryzek P, et al. Interventions complementing surgery as part of multistage treatment for hypoplastic left heart syndrome: one center's experience. Pediatr Cardiol 2009; 30: 106-113.

2. Moszura T, Mazurek-Kula A, Dryżek P, et al. Interventional treatment of patients with hypoplastic left heart syndrome and elevated pulmonary artery pressure - a single centre experience. Pol Przegl Kardiol 2008; 3: 202-206.

3. Moszura T, Mazurek-Kula A, Dryzek P, et al. Percutaneous interventions in multistage treatment of hypoplastic left heart syndrome. Pol Przegl Kardiol 2005; 5: 405-413.

4. Moszura T, Mazurek-Kula A, Dryżek P, et al. Uncommon stenting procedures in hypoplastic left heart syndrome treatment in children. Folia Cardiologica 2005; 12: 790-794.

5. Zeltser I, Menteer J, Gaynor JW, et al. Impact of re-coarctation following the Norwood operation on survival in the balloon angioplasty era. J Am Coll Cardiol 2005; 45: 1844-1848.

6. Chessa M, Dindar A, Vettukattil JJ, et al. Balloon angioplasty in infants with aortic obstruction after the modified stage I Norwood procedure. Am Heart J 2000; 140: 227-231.

7. Douglas WI, Goldberg CS, Mosca RS, et al. Hemi-Fontan procedure for hypoplastic left heart syndrome: outcome and suitability for Fontan. Ann Thorac 2007; 22: 55-59.

8. Nakano T, Fukae K, Sonoda H, et al. Follow-up study of pulmonary artery configuration in hypoplastic left heart syndrome. Gen Thorac Cardiovasc Surg 2008; 56: 61-62.

9. Sreeram N, Emmel M, Ben Mime L, et al. Perioperative placement of stents for relief of proximal pulmonary arterial stenoses in infants. Cardiol Young 2008; 18: 158-164.

10. O'Laughlin MP, Perry SB, Lock JE, et al. Use of endovascular stents in congenital heart disease. Circulation 1991; 83: 1923-1939.

11. Rao PS. Static balloon dilatation of the atrial septum. Pediatr Cardiol 1996; 17: 349-350.

12. Webber SA, Culham JA, Sandor GC, et al. Balloon dilatation of restrictive interatrial communications in congenital heart disease. Br Heart J 1991; 65: 346-348.

13. Stumper O, Gewillig M, Vettukattil J, et al. Modified technique of stent fenestration of the atrial septum. Heart 2003; 89: 1227-1230.

14. Dähnert I, Riede FT, Razek V, et al. Catheter interventional treatment of Sano shunt obstruction in patients following modified Norwood palliation for hypoplastic left heart syndrome. Clin Res Cardiol 2007; 96: 719-722.

15. Dryzek P, Mazurek-Kula A, Moszura T, et al. Right ventricle outflow tract stenting as a method of palliative treatment of severy tetralogy of Fallot. Cardiol J 2008; 15: 376-379. 